\title{
Protests and the political capital of anti-systemic opposition in Russia, using the example of Aleksey Navalny's 2017 anti-regime protests
}

\section{Introduction}

In this article we consider the anti-systemic opposition to consist of those political forces which aim to change the system created by Vladimir Putin, are not extremist groups, i.e. they do not interfere in the generally accepted meta-order of society, and which aim to promote the development of the state according to a clause in the accepted Constitution of the RF, which states that "Russia is a democratic federal law-bound State with a republican form of government"2. Daria Tatarkova believes that anti-systemic opposition should be described as organisations and movements which oppose the existing regime, which recognise the system of political values that is legitimised by the majority of society and which are also not of an extremist nature ${ }^{3}$. One of the most energetic representatives of this milieu is the politician and anti-corruption activist Aleksey Navalny. Here we shall look into the dependence between the anti-regime protests which Navalny organised with his associates in 2017, and his political capital.

The political capital of any political force means the trust, good will and support that its representatives enjoy in society, but also the influence of its individual representatives on public opinion and other political entities. This capital will be something like an invisible currency which politicians can exploit to mobilise voting citizens or which

This work was supported by the National Science Centre (Poland) under Grant number 2015/19/B/ HS5/02516

2 'Constitution of the Russian Federation. First Section. Chapter 1. Article 1' available at: http://www. constitution.ru/en/10003000-02.htm, Accessed 17 October 2017.

3 Д.Ю. Татаркова, Несистемная оппозиция как специфика презентации в печатных СМИ, „Полис" 2013, No. 4, p. 132. 
they can - once they are in power - spend on political reforms ${ }^{4}$. Sorensen and Torfing, who focus on political capital on the level of the individual, state that "political capital refers to the individual powers to act politically that are generated through participation in interactive political processes" ${ }^{\prime \prime}$. In a nutshell, for Sorensen and Torfing, political capital is a "mix of what people have, what they do and who they are"6.

According to Daniel Schugurensky, there is a large number of factors that strengthen or hinder political capital, and of these he mentions knowledge, skills, attitudes, closeness to those in power and personal resources ${ }^{7}$. Knowledge is familiarity with the law, the norms and issues necessary for effective participation in political processes. Awareness of how the system built by Vladimir Putin works can make action, the choice of a political strategy and the search for "windows of political opportunities" to fight with the regime easier for opposition politicians. In order to be able to influence the political process better, in addition to knowledge, such competences as the ability to analyse, to make the comparisons necessary to understand, interpret and evaluate a societal situation, the ability to negotiate, persuade, mobilise, argue effectively and speak in public with ease are important. The third component that influences the level of political capital is attitudes of such as resilience, motivation, regularity and the belief in the purpose of what one is doing. The next factor - closeness to power - refers to the distance (both objective and symbolic) between the citizen and the representatives of political power. In the context of the analysis below, the aspect of symbolic "closeness to power" is of prime interest, which means the presence in society of people whose opinions on important socio-economic-political questions are similar to those of the authorities. If one assumes, that the aim of the anti-systemic opposition is not to be co-opted into the existing system or any sort of cooperation with representatives of the current existing government, this point may be reformulated thus: the opposition presents itself as a political force that the majority of citizens would see as being in power. In other words, it is a political force whose values, views and opinions are consistent with the views and values of society. The final factor is personal resources, including institutional and financial ones, which to a large extent determine the opportunities to influence the political process.

In order to avoid the extreme, binary assessment of the situation, which overestimates the impact of Navalny's 2017 protests on Russia's domestic policy or marginalises it completely, this article intends to analyse the influence of these protests on the level of Navalny's political capital. The article will refer to each of the components of political capital, to see what sort of changes in these areas give result in anti-regime protests.

4 R. French, Political capital, "Journal of Representative Democracy", vol. 47, 2011 issue 2, p. 215-230, available at: https://www.researchgate.net/publication/261709373_Political_Capital.

5 E. Sørensen \& J. Torfing, Network Politics, Political Capital and Democracy, "International Journal of Public Administration" 2003, vol. 23, no 6, p. 610.

6 Ibidem, p. 625.

7 D. Schugurensky, Citizenship Learning and Democratic Engagement: Political Capital Revisited, Paper presented at the 41st Annual Adult Education Research Conference. Vancouver: AERC, June 2-4, 2000. Published in Conference Proceedings, p. 419-420. 
In the view of the difficulties in estimating the precise level of political capital of a given politician, information regarding political capital may be obtained by comparing the levels of the various components which make up the political capital of several different politicians ${ }^{8}$. Another means is to investigate whether a given event inspired by a politician, for example an election campaign (s)he ran, a reform (s)he introduced or a different decision or political action, increases or diminishes his/her political capital. This article makes reference to the last of these means, because it concentrates on obtaining information on the direction of the changes in the political capital of Aleksey Navalny, as a result of the remarkable protests he organised in 2017.

This study seeks not only to make a much-needed contribution to the literature on the potential of anti-systemic opposition in Russia, but may also, through an analysis of its strategy for fighting the regime, contribute to a clearer understanding of the nature of the Russian political system.

In order to realise this aim, we shall analyse the themes of the protests organised by Aleksey Navalny's movement in 2017, i.e. the anti-corruption protests of $26 \mathrm{March}$, 12 June and 7 October 2017, and we shall compare the two types of protest in terms of their dynamics, geographic breadth and the reaction of those in the centre of power to these events. We shall also consider whether, and to what extent, the protests altered society's perception of Navalny and the scale of his influence on political processes in Russia. The data on the participants and the geography of the 2017 protests are taken from the website Meduza and OVD Info'. The data have also been used regarding how society perceived the protests, which were to be found on the webpage of the Levada Center ${ }^{10}$. Some of the information on how Navalny's activity was assessed by those closest to him and also on the factors which motivate people to work together with him was obtained from interviews with workers from Navalny's regional headquarters in St. Petersburg and Moscow ${ }^{11}$.

${ }^{8}$ K.L. Casey, Defining Political Capital: A Reconsideration of Bourdieu's Interconvertibility Theory, 2008, available At: https://about.illinoisstate.edu/critique/Documents/Spring\%202008/Casey.pdf. accessed 13 January 2018.

9 Сколько тюдей вышли на улицы 26 марта и сколько задержали? Карта протеста, "Meduza", 27 March 2017, available at: https://meduza.io/feature/2017/03/27/skolko-lyudey-vyshli-na-ulitsy-26-marta-i-skolko-zaderzhali-karta-protesta, accessed 10 June 2017;. 12 июня на улицы вышло больше людей, чем 26 марта Карта протестов «Медузы» и «ОВД-Инбо». Самые полные данHыle, „Meduza” 13 June 2017, available at: https://meduza.io/feature/2017/06/13/skolko-lyudey-protestovali-12-iyunya-i-skolko-zaderzhali, accessed 15 July 2017; 7 октября: протестная карта. Где и сколько людей вышло, сколько задержали Совместньй проект «Медузы» и «ОВД-Инфо», „Meduza” 8 October 2017, available at https://meduza.io/feature/2017/10/10/7-oktyabrya-protestnaya-karta-gde-i-skolko-lyudey-vyshlo-skolko-zaderzhali, accessed 15 January 2018.

10 Е. Кузнецова, В. Дергачев., Июньские протесты не добавили Навальному популярности, https://www.levada.ru/2017/07/17/iyunskie-protesty-ne-dobavili-navalnomu-populyarnosti/, Levada.ru July 2017, at: https://www.levada.ru/2017/07/17/iyunskie-protesty-ne-dobavili-navalnomu-populyarnosti/, accessed September 20, 2018.

11 Navalny's co-workers in Saint Petersburg, (9 February 2018). Personal interview; Navalny's co-workers in Moscow, (18 April 2018). Personal interview. 


\section{Navalny's protest and the social movement theory}

In the literature on the social movement much space is given over to the significance of the leader who organises collective action. The leader plays a vital role in creating a network of contacts when society, or specific societal groups, is first being mobilised. It is he or she who shows that remaining within the circle of one's own people and submitting to the decisions of those in power is not the only course of action, and he or she suggests collective action as an alternative. The leader is viewed by the group as trustworthy, articulate, socially mobile, having organisational skills and a broad network of contacts, and he is fully conversant with the law. By the same token he has considerable social capital at his disposal ${ }^{12}$. Here the question arises as to whether the influence is also reciprocal, in other words whether the protests organised by a leader can also affect his/her own position in politics.

The validity of the organisation of anti-regime protests by the opposition leaders arises from aims that the political milieu sets itself. The main aim of the opposition is to change the political system built by Vladimir Putin and to democratise Russia. This main aim is supported by three specific aims. These are, to put pressure on those in power and to raise the costs of maintaining the authoritarian system, to turn the society against Putin's regime, and to convince as many citizens as possible of one's own political programme ${ }^{13}$.

For leaders of the anti-systemic opposition, the system restricts opportunities to fight for power and to apply for important political offices in the state via competitive elections. Therefore, they try out other methods and means of expressing their opposition to the actions of the ruling elite and of making citizens aware of the weaknesses of the current political system.

They practise contentious politics, which is a natural element of socio-political life ${ }^{14}$. In democratic systems this is enriched by traditional forms of political participation associated with democratic institutions and it draws attention to social problems. In non-democratic systems, the development of contentious politics is hindered by the high level of repression on the part of the government and the effective control of those social and material resources necessary for building non-state structures of collective action ${ }^{15}$.

At the same time, it is worth emphasising that both in the social perception and political practice of Putin's Russia, there is a considerable difference between "socio economic" and "political" protest actions. Socio-economic protests are perceived as one of

12 К. Клеман, Подъем гражданских протестных движений в закрытой политической системе: потенциальный вызов господствующим властным отношениям?, 2006, http://www.isras.ru/ files/File/publ/Vyzov_vlast_otnosch_Kleman.pdf, p. 8.

13 A. Stepan, On the Tasks of a Democratic Opposition, "Journal of Democracy" 1990, vol. 1, no 2, p. 41-49.

14 V. Nechai, D. Goncharov. Russian Anti-corruption Protests: How Russian Twitter Sees It?, "Digital Transformation and Global Society" 2017, vol. 21, no 33, p. 271.

15 T. Frye, A. Yakovlev, Elections and Property Rights: A Natural Experiment From Russia, "Comparative Political Studies" 2016, vol. 49, no. 4, p. 499-528. 
the permissible means of expressing one's expectations of a specific problem of a social nature. These protests are often linked to a decision of representatives of the local elite and their goal is to demand that this decision be changed ${ }^{16}$. "Rather than questioning the legitimacy of the regime, these protesters are voicing their discontent by appealing to the authorities on the level above that viewed as responsible for the problems, simply informing them about the problems their subordinates are creating" ${ }^{17}$. Unlike socio-economic protests, political protests are seen as illegitimate or even illegal, and furthermore, government propaganda often presents these protests as attempts, inspired from abroad, to start a revolution in Russia and overthrow the system.

It is worth remembering what commonly motivates people who take part in protests in Russia to do so. As Alfred B. Evans Jr. rightly notes, many protesters are seeking changes to specific policies or the implementation of those policies, rather than demanding a fundamental change in the nature of their country's political regime. Abstract slogans about democracy or human rights do not mobilise people to take to the streets to the same extent as those concerning specific problems, politics or government decisions.

The sociologist Stephan Goncharov from the Levada Center points out, that people react to a much greater degree to problems of a socio-economic nature than politi$\mathrm{cal}_{\text {ones }}{ }^{18}$. The majority of the population understands and is prepared to support the protests of lorry drivers, doctors and teachers (70\% of respondents were prepared to support these social groups), while Russians understand the motives of oppositionists who organise political protests to a much smaller degree (Volkov 2018). In connection with this the effective organisation by a representative of the anti-systemic opposition of political protests involving many thousands of people in a non-democratic regime, such as Russia, is an interesting field for research. Protests, especially anti-regime ones, are among the more serious and, effects-wise, unpredictable challenges for authoritarian regimes.

Of the many factors which influence the success of a mobilisation by the anti-systemic opposition is society's level of preparedness to participate in protests, which in turn depends on their ability to communicate their oppositional message to potential supporters, and on the quality and force of the effect of this message.

It is worth remembering that the literature of the subject often combines the phenomenon of leadership with the concept of authority. However, it should be remembered that although leadership and authority may coexist, it is not an obvious relation-

16 A. B. Evans, Jr., Protests in Russia. The Example of the Blue Buckets Society, "Demokratizatsiya: The Journal of Post-Soviet Democratization" 2018, vo. 26, no 1, p. 4-5.

17 J. Østbø, Between Opportunist Revolutionaries and Mediating Spoilers: Failed Politicization of the Russian Truck Drivers' Protest, 2015-2016, "Demokratizatsiya: The Journal of Post-Soviet Democratization" 2017, vol. 25, no 3, p. 283.

18 'DW, Соииолог о том, как Навальный влияет на протесты в Pоссии, , November 2017, available at: http://www.dw.com/ru/sociolog-o-tom-kak-naval'nyj-vlijaet-na-protesty-v-rossii/a-41281904, accessed 28 September 2018. 
ship. The tendency to combine these two categories suggests a leader's authority and well-established social position in some circles, which allows to make assumptions, even if only approximate, of the success of a protest action.

The authors investigating the phenomenon of a leader in social movements also describe how the specific practices of the leader determine the effectiveness of the action. They point to relationship, story, strategy and action. The first two concepts require some explanation and will help to understand the Navalny's case better. The relationship means interpersonal connections of leader that link individuals, networks, and organizations ${ }^{19}$. A social movement leader also tells a new "story". A skilful articulation of social concerns draws attention to protest, thus the strength of public narrative is a second important leadership practice.

In the context of the above theory, the case of Alexei Navalny seems to be really special and extremely rich heuristically. The oppositionist - on the eve of the organization of the protest action - was a politician with extremely small public support (1 percent), who was just starting his election campaign (by March 2017 Navalny opened only 12 regional branches ${ }^{20}$. Therefore, he did not have any support teams and regional branches distributed in different parts of the country. What is more, at that time there were no external circumstances that could become a catalyst for increasing the protest mood - that is, no unpopular reform, decision of the ruling elite, elections or a sudden economic downturn.

The power and innovation of the oppositionist stems from the fact that - with the aim of fighting against the non-democratic system and based on the opposition's eternal objections to the corruption of the Russian authorities - he himself generated a motive for the protest action "He is not Dimon to you" and used it at the time of his own choice, not at the moment imposed by some external circumstances.

\section{The main theme of the protests}

Willingness to take to the streets depends to a large extent on the skilful strengthening of the feelings of as many citizens as possible, namely those of anger and frustration with the policies of the representatives of power $^{21}$. These negative emotions (anger,

19 M. Ganz, Leading Change Leadership, Organization, and Social Movements, [in:] N. Nohria \& R. Khurana (eds.) Handbook of Leadership Theory and Practice, Excerpted from Chapter 19, Harvard Business Press Boston, Massachusetts 2010, available at: http://marshallganz.usmblogs.com/ files/2012/08/Chapter-19-Leading-Change-Leadership-Organization-and-Social-Movements.pdf, accessed 7 March 2019.

20 Приблизительное расписание открытий штабов, VK,16 February 2017, available at: https:// vk.com/topic-55284725_34990538, accessed 16 May 2018.

21 R. Collins, Social movements and the focus of emotional attention, [in:] J. Goodwin, J. M. Jasper \& F. Polletta (eds.) Passionate politics: Emotions and social movement, Chicago, IL: University of Chicago Press 2001; D. Della Porta \& M. Diani, Social movements, Oxford: Blackwell 1999; Goodwin J. \& Jasper J. M. (eds.), Rethinking social movements: Structure, meaning, and emotion, Lanham, MD: Rowman and Littlefield 2004. J. Goodwin, \& S. Pfaff, Emotion work in high-risk social movements, 
frustration) have a fundamental significance in social movements; they create "emotional mobilisation"22 and give "movement to social movements" ${ }^{23}$. According to a volunteer at Navalny's headquarters in St Petersburg, one of the most important tasks of protest actions is to ensure that people who are critical of the system headed by Putin understand that they are not alone and that they feel their own strength and anger. ${ }^{24}$ These three feelings are key: a sense of strength, community and anger. The analysis of the stages of emotional mobilisation may help in answering one of the questions that in Sydney Tarrow's opinion are worth asking when researching political contestation. This question concerns how one should explain the reasons why people who have for a long time put up with a particular situation, a particular "state of affairs" in the country, begin to unite in order to declare their opposition to it, to stand up to the ruling elite ${ }^{25}$.

The principles of emotional mobilisation were used successfully by Aleksey Navalny during the anti-corruption protests of 2017. These events are interesting for the researcher because Navalny succeeded in mobilising part of society around the theme of the corruption of the government, even though the problem of abuses by Russian rulers appears time and again in Russian history and is known to Russian society. The strength of Navalny's mobilisation strategy was the fact, that he increased awareness of specific abuses at the apex of the Kremlin pyramid. In a film posted on YouTube at the beginning of March 2017 "He is not Dimon to you"26 Aleksey Navalny presents the outcomes of the investigations of the "Anti-corruption Foundation", which he founded himself and which is concerned with the corruption of Dmitri Medvedev and his associates. The lack of reaction from the president and the prime minister to the facts revealed in the film motivated Navalny to organise protests across Russia on 26 March 2017.

According to Prof. Aleksey Titkov, the arrogant attitude of the government after the film was shown, contributed to effective mobilisation ${ }^{27}$. This was offensive behaviour, full of self-importance and the conviction that the government is above the law and that those caught engaging in corruption are not even obliged to explain to society what they were doing, not to mention being held liable for the abuses. Investigating the main themes of the protests in Russia, thus far shows that a high turn-out is guaranteed

[in:] J. Goodwin, J. M. Jasper \& F. Polletta (eds.) Passionate politics: Emotions and social movement, Chicago, IL: University of Chicago Press 2001.

22 J. M. Jasper., Emotion and Motivation, [in:] Robert E. Goodin and Charles Tilly (eds)., Oxford Handbook of Contextual Political Studies. Oxford: Oxford University Press 2006, p. 157-171.

23 R. Eyerman, How social movements move: Emotions and social movements [in:] H. Flam and D. King (eds.), Emotions and social movements. Abingdon: Routledge 2005, p. 41-57.

24 Navalny's co-workers in Saint Petersburg, (9 February 2018). Personal interview.

25 S. Tarrow, Power in Movement: Collective Action, Social Movements and Politics. N.Y., Cambridge: Cambridge University Press 1994, p. 87.

${ }_{26}$ Anti-Corruption Foundation. 2017. He is Dimon to you. At: https://www.youtube.com/ watch?v=qrwlk7_GF9g, accessed April 13, 2018.

27 A. Titkov (12 April 2018). Personal interview. 
by slogans that relate to the actions or attitudes of the representatives of power, which are perceived by some members of society as blatant arrogance on the part of the government and disregard for the citizen ${ }^{28}$.

At the same time, the mobilisation initiated by Navalny was not centred on abstract slogans, claiming that the representatives of power steal and cheat, but on specific evidence of the abuses and lack of response from the Kremlin to the accusations made. Navalny's success is down to the fact that he was able, as it were, to create a situation that became ideal "soil" for protests - from the film about Medvedev to the demand for answers and the protest resulting from the lack of reaction from the Kremlin.

Considering that the protest did not yield any answers from the decision-making elite to the allegations made in the film, on 12 June 2017 Navalny organised another protest "We demand answers", which outdid the March protest both in terms of the number of participants and its geographic breadth.

\section{The geography of the anti-corruption protests and the number of participants}

Navalny's anti-corruption protests show clearly that it is not only Moscow and St Petersburg that are not afraid of publically expressing their opposition to the abuses of the representatives of power and are prepared to participate in joint protests. Six cities with a population of less than 100,000 inhabitants participated in the protest of 26 March, and in the protest of 12 June as many as 46 such cities (including six with a population of less than 20,000) took part. In some towns the number of protesters (12 June) was small, for example five to seven people in Kungur, seven people in the town of Kotlas, seven to eleven in Gelendzhik, Soligach - four and Galich - two. This points to the high degree of non-conformity of those who took part in the protests in these places, and at the same time it explodes the myth of the absolute loyalty to Putin of those living in smaller towns. The analysis of the proportion of Russians who took part in both protests, the March and June ones, reveals that in the majority of cities the number of participants tended to increase.

Although the geographic breadth of the protests was impressive, it would be worthwhile to look closely at the number of participants in the protests in individual localities, and more specifically to compare this with the number of inhabitants. In the largest cities the proportion of the population that took part in the protests was as follows - in Moscow $0.21 \%$ in the March protests and 0.39\% in June, and in St Petersburg 0.20\% and $0.24 \%$ respectively. The highest participation rate was recorded in Saratov, $0.35 \%$ in the March protests and $0.59 \%$ in June. In no other city, nor in any other protest analysed in this text, did the proportion of participants exceed $0.5 \%$ of the population ${ }^{29}$.

28 Examples are „For Fair elections protest” or Russian pensioners' protest from 2005.

29 The percentages are calculated on the basis of the upper boundary of the data on the number of participants (so if, for example, there were between 10,000 and 20,000 participants in city X, we take 20,000). 
These figures prove that the anti-corruption protests, although the largest since the protests of 2011/2012, did not achieve a level of participation which would indicate a high degree of delegitimisation of the regime.

In the light of the question regarding the relationship between participation in the anti-regime protests organised by Navalny and social support for him, one should consider the protests of 7 October 2017, which were an expression of support for him as a presidential candidate.

The protests on 7 October 2017 attracted a smaller number of participants than expected. According to Meduza and OVD Info, between 2,560 and 21,520 people took part in the protest in 79 Russian cities. The number of cities was mostly the same as the number of Navalny's regional headquarters that were open at the time. This dependence shows that there was a success in stirring protestors to action mainly in those cities where Navalny has regional branches. Street agitations by Navalny's volunteers, the web pages of each of Navalny's headquarters, both on Facebook and VKontakte, contributed significantly to the successful organisation of the protests in cities where Navalny has an active headquarters. The biggest protests in Moscow and St Petersburg brought together 3,000 and 10,000 people respectively.

According to Vladimir Gelman, negative mobilisation (against corruption) is always more effective than positive (in support of Navalny) ${ }^{30}$. This is confirmed by the work of Lyubov Borusyak, who interviewed young people participating in the anti-corruption protests. On the one hand, the young people who were Borusyak's respondents, named Navalny as the only oppositionist in contemporary Russia who is capable of organising a mass protest and mobilising people to take to the streets. On the other hand, at no stage did the respondents mention their willingness to support Aleksey Navalny as the reason why people took part in the protests ${ }^{31}$. A comparison of the anti-corruption protests with the October protest in support of Navalny allows us to understand the so-called mechanism of a "one-off" manifestation of one's attitude towards a specific problem. If a protest is against corruption, then even if it is organised by a specific leader, the participants express their dissatisfaction with corruption and not their support for the main organiser. It is similar in the case of protests against war, against a breach of a particular article of the constitution, or against election rigging.

The protests did not result in two more obvious aims being met. Namely, they did not succeed in putting pressure on the government and registering Aleksey as a presidential candidate. They also did not succeed in influencing the attitude of the government, i.e. gain answers relating to the accusations of corruption and abuses levelled against Dmitri Medvedev, not to mention the changes or reforms that could be a consequence of Navalny's anti-corruption investigations.

30 V. Gelman (5 February 2018). Personal interview.

31 Л.Ф. Борусяк, Молодые участники протестов: почему они выходят на улицы? ХІХ Апрельская международная научная конференция по проблемам развития экономики и общества, 10-13 апреля 2018 https://conf.hse.ru/2018/program/, p. 3. 


\section{Political capital of Alexey Navalny}

However, these results do not mean that the protests have not affected the growth in Navalny's political capital. As mentioned earlier, political capital is a phenomenon that aggregates many different components. Therefore, it is not possible to investigate the extent to which a given situation influences trends in changes in political capital and the direction of these changes without examining what their effect is on the individual components of the political capital.

The first component is knowledge, familiarity with the rules of the game of a given political system. In the case of the anti-systemic opposition, constant stepping out of not only one's own comfort zone, but also that of the representatives of the ruling elite allows one to identify better the current strategy of the power centre for dealing with expressions of dissatisfaction with their politics. The actions of the anti-systemic opposition are a constant search for effective ways of putting pressure on the government. It will not be possible to find an effective method without being pro-active and constantly making new attempts. If a ruler learns to be an effective autocrat through experience, and "among other factors, the outcome of this process - that is, whether autocracy materialises or not - depends on the learning process"32, then an oppositionist can also learn to stand up to the ruler from experience.

The organisation of street protests has allowed Navalny to test how far the effects of his slogans and protest themes of a clearly political nature, but of varying provenance, can make themselves heard. In the protests of 26 March and 12 June 2017 the theme was corruption at the top of the power centre. What was special about this was that apart from its decidedly political flavour, it concerned socio-economic problems. The protest of 7 October was strictly concerned with the elections and support for Navalny as a presidential candidate. Five times as many people took part in the protests on 26 March and 12 June as on 7 October, thereby confirming the trend that even if people perceive an event to have only an indirect link to their own interests, it enjoys a greater level of societal participation. In the anti-corruption protests it was easier to identify this relationship than in those protests that demand that a presidential candidate be registered, even one who has been unfairly belittled and fought off by the Kremlin.

The second important component of political capital is skills that are particularly useful in influencing the political process, such as the ability to mobilise, negotiate, persuade and convince. Through the 2017 protests, Navalny confirmed his ability to mobilise. Public displays of the extent of civil disobedience present a serious risk for authoritarian rulers ${ }^{33}$. As Duvanova rightly observes, "for the first time since Putin took

32 I. S. Grigoriev\& A. A. Dekalchuk, Collective learning and regime dynamics under uncertainty: labour reform and the way to autocracy in Russia, "Demokratizatsiya: The Journal of Post-Soviet Democratization" 2017, vol. 24, no 3, p. 482.

${ }_{33}$ G. B. Robertson, The Politics of Protest in Hybrid Regimes: Managing Dissent in Post-Communist Russia, New York: Cambridge University Press 2011; Ching Kwan Lee and Yonghong Zhang, The Power of Instability:Unraveling the Microfoundations of Bargained Authoritarianismin China, "Amer- 
office the opposition appears to be driving the protest agenda" ${ }^{34}$. The opposition is setting the agenda. A peculiar role-reversal ensued: in implementing his decision to organise protests Navalny became the active subject in Russian politics, the government - a subject on the defensive, reacting to his actions.

Remaining with the subject of effective mobilisation, it is worth taking note above all of the geographic breadth of Navalny's anti-corruption protests. The mobilisation of people from 99 cities in March and 154 in June confirmed his organisational skills, and also demonstrated that not only had he found a theme that resonated with the experience of many Russians, but he was also, as mentioned earlier, able to present it in such a way that it triggered protests. On the one hand the anti-corruption protests concerned specific accusations directed at the prime minister, on the other hand the specific abuses mentioned in the film present an image of the whole system, its origins and the nature of its corruptness. This means that public trust not only for corrupt lowrank officials but also for the whole of the vertical power structure right up to Vladimir Putin's closest colleagues, and therefore right up to Putin himself, is being undermined. Corruption means that the president's ultimate, unwritten agreement with the Russian people is challenged. It presupposes that the citizens of Russia will patiently put up with sanctions and the inconveniences associated with them, in exchange for which Putin will defend Russia and the Russians against the supposed threat from the outside. In the face of corruption the logic of this agreement becomes incomprehensible: why should the average Russian tighten his or her belt, while top state officials are becoming richer and richer? According to Navalny, this corruption is "the most important reason for the poverty of citizens" ${ }^{\prime 35}$. Given the severity of the accusations, it will be difficult for the government to calm citizens' anger. ${ }^{36}$ Andrey Kolesnikov is right to point out that above all the most recent protests concern injustice, and therefore fall within the field of ethics. ${ }^{37}$ Therefore the ruling elite must eradicate the cause of injustice in order to win back the support of the protesters. The cause of the injustice, however, is to be found in the system itself, and so requires reform on the level of the system. The lack of decisions in this area undermines the axionormative system on which the Russian political

ican Journal of Sociology” 2013, vol. 118, no. 6, p. 475-508; V. J. Bunce \& L. Wolchik, Defeating Authoritarian Leaders in Postcommunist Countries. New York: Cambridge University Press 2011.

34 D. Duvanova, Russians are protesting. Part 5 Now the opposition is setting the agenda, "Washington Post" March 2017, at: https://www.washingtonpost.com/gdpr-consent/?destination=\%2fnews\% $2 \mathrm{fmon}$ key-cage $\% 2 \mathrm{fwp} \% 2 \mathrm{f} 2017 \% 2 \mathrm{f} 03 \% 2 \mathrm{f} 31 \% 2$ frussians-are-protesting-why-part-5-now-the-opposition-is-setting-the-agenda\%2f\%3f\&utm_term=.b9e10a9636ef, accessed September 18, 2017.

35 M. Omelicheva, New wave of protests in Russia (the old and the new, "PONARS Eurasia 2017, at: http:// www.ponarseurasia.org/article/new-wave-protests-russia-old-and-new, accessed July 19, 2017.

36 T. P. Gerber, Russians are protesting. Part 2: Any government response will bring out more protesters, "Washington Post" March 2017, at: https://www.washingtonpost.com/news/monkey-cage/ $\mathrm{wp} / 2017 / 03 / 31 /$ russians-are-protesting-why-part-2-any-government-response-will-bring-outmore-protesters/?utm_term=.2ac3ec138c76, accessed September 18, 2017

37 A. Kolesnikov, New Protests Question Russia's Social Contract, "Carnegie Europe" 2017, at: http:// carnegieeurope.eu/strategiceurope/71283, accessed February 20, 2018. 
regime is founded - and this is an element of one of the most important political aims that Navalny sets himself.

The third aspect that influences the level of political capital is attitudes, such as: resilience, motivation, systematicity and a belief in the purpose of what one is doing. The protests organised in 2017 are an expression of these traits of Aleksey Navalny. He continued to organise protests despite difficulties created for him by the local officials, despite arrests for his associates and also for him himself, despite searches at the Anti-Corruption Foundation as well as the confiscation of electrical equipment and other important items.

As Grigorii Golosov rightly observes, "what is special about the activity of the political opposition consists in the fact that the effort it puts in is usually greater than the effect of this work" ${ }^{38}$. However, it is worth remembering that the positive outcomes of specific activity can reveal themselves gradually because they constitute an important link in the longer process of change. If we speak of the political change that Aleksey Navalny is aiming at then we should bear in mind that one of the more important favourable factors in this change is the dominant view among the elite and citizens that change is possible. Jennifer Gandhi and Ellen Lust-Okar claim that the opposition's strategy for action and citizen-level behaviour are influenced by "their perception of the likelihood of regime change"39. Navalny's attitude and behaviour over the course of his political activity, and especially during his 2018 election campaign, epitomises the conviction that change for the better is possible. His energy and enthusiasm attract many young people who have a negative attitude towards the current ruling elite. They may not agree with all the points in Navalny's programme, but in him they see their only hope for an effective fight with the regime.

A significant effect of Navalny's resilience and his will to continue to battle with the regime is the growth in his recognisability. This grew from 47\% in February 2017 to $55 \%$ in March. Name recognition is one of the standard measurements of social capital and may be converted into other types of capital. It is not possible to build social support unless one is recognised, so this very clear result of the protests has had a positive effect on Navalny's political capital.

Another aspect of political capital is closeness to power, which we understand symbolically as the reciprocal superimposition of visions of the world, views, the values of a given politician and society. Between 2008 and February 2017 support for Navalny remained on a level of 1\%. In April 2017 a growth to $2 \%$ was noted, and since then this two-per-cent support has not fallen. This is scanty support, but the protests have triggered a positive trend in this area.

38 G. V. Golosov, Die ideologischen Positionen der Regierung und der Opposition in Russland, "Russland-Analysen" 2018, no 355, p. 2. At: http://www.laender-analysen.de/russland/pdf/RusslandAnalysen355.pdf, accessed September 28, 2018.

39 J. Gandhi \& E .Lust-Okar., Elections under Authoritarianism, "Annual Review of Political Science" 2009, no 12, p. 416. 
It is worth remembering that Navalny pursues his activity and communicates chiefly with the aid of the Internet. Communication with broad segments of society, for whom the issue of social justice is exceptionally important, is possible, but through the medium of federal television channels which are controlled in turn by the power centre. Activity on social networks, which Navalny and his team have mastered to such a high degree, is the excellent capital for the future, although at present only a few percent of the population, mainly urban youth, have been successfully mobilised through these channels. However, compared to the other democratic forces in Russia, the effect of Navalny's activity can be considered a real breakthrough ${ }^{40}$.

Another breakthrough is the change in the way that political protest is perceived. According to the political scientist Abbas Gallyamov this type of protest has become "socially acceptable", and the number of people who support the protesters has already exceeded the number of those who condemn them: "the taboo of street politics has been removed. Russians no longer fear Maidan"41.

One of the essential consequences of the 2017 anti-regime protests - also from the point of view of the anti-systemic opposition - is the fact that the experience of taking part in them increases the political awareness of their participants. This is confirmed by the sociological research of Lyubov Borusyak ${ }^{42}$, who conducted interviews with young people that took part in the protests on 26 March and 12 June $2017^{43}$, whilst interviews carried out after the second protest showed that young people are more aware of their own views, that they are able to order their arguments and articulate their beliefs. By the same token, the first March protests motivated some participants to become more interested in politics, to think about their political views. This does not mean that these views are the same as Navalny's, although their greater interest in politics and greater political awareness increase their need to defend their own interests and will to be involved in politics. Social activation is an important component of Navalny's mission. Even the motto of his blog is "the final battle between good and neutrality" (final'naya bitva mezhdu dobrom i neutralitetom $)^{44}$, where neutral means passive, regardless of the political reality. As Lev Gudkov has shown in his analysis about the Putin regime, it was stable as long as the majority of the population was passive. ${ }^{45}$ The greater number of citizens who are aware is a threat to the existing political order as a whole. The second anti-corruption protest on 12 June, which in terms of the number of its participants and geographical breadth had a greater impact than the previous one, demonstrated that "for a growing number of Russians-not just in Moscow and St. Petersburg, the traditional centres of political activism,

40 Д. Волков, Предпосылки для осенних протестов, https://www.levada.ru/2018/08/16/predposylki-dlya-osennih-protestov/, accessed September 18, 2018.

41 Е. Кузнецова, В. Дергачев, op. cit.

42 Л. Ф. Борусяк, op. cit.

43 During the protest of 26 March 2017 Lyubov Borysyak carried out 40 in-depth interviews with young protesters and 50 interviews with young people on 12 June 2017.

44 Available at: https://navalny.com/, accessed September 20, 2018.

45 L. Gudkov, The nature of Putinism, "The Public Opinion Herald" 2003, vol. 3, no 101, p. 11. 
but also in the regions-self-awareness as citizens and yearning for respect from the state are becoming stronger than fear of repression" 46 .

The final component of political capital is resources. Here we include institutional resources, human resources and financial resources. In evaluating the influence of the protests on the quantity and quality of these resources one should bear in mind that the street actions organised by Navalny were part of the larger project which was his presidential campaign. One component of it was his visits to and meetings in various cities of Russia as well as the opening of regional election campaign headquarters. On the one hand, the protests were an important part of the activity of the already existing headquarters, and on the other some of the young people who had been mobilised during the anti-corruption protests later lent their support to Navalny's election headquarters in their own cities. In total during his election campaign he opened 81 headquarters. Their presence on social media has made it possible to follow their exceptional work, involvement in local projects and minor successes. In terms of the unusual energy of the work of its headquarters, Navalny's campaign - in comparison to those of other candidates - was the most decisive and substantial. Navalny has created a modern, horizontal structure, made up not only of active but above all of motivated individuals who are not afraid to take the risk of working for the current president's greatest rival.

As far as human resources are concerned, one of the most important of Navalny's tasks is not to lose the support of those who were mobilised during the protests, or more broadly, during his election campaign ${ }^{47}$. In the opinion of Aleksander Kynyev, Navalny has a chance of keeping the network of supporters - mostly volunteers and young associates - that he formed in 2017 and which was reconstructed following the presidential election $s^{48}$, if within two years he is able to show an alternative career path. In this context an important question is the possibility of registration of Navalny's party, which would to a large extent make this task easier as it would allow many of his supporters to work within its structures ${ }^{49}$.

An important resource is financial capital. For non-registered opposition groups in Russia, of which one example is Navalny's team, a source of finance is crowdfunding ${ }^{50}$. There is no way of abstracting data regarding how the protests themselves influenced crowdfunding during Navalny's election campaign, but monthly financial reports on

46 V. V. Kara-Murza, The Kremlin Emboldened: Putin Is Not Russia, "Journal of Democracy" 2017, vol. 28, no 4, p. 114.

47 V. Lasnier, Demobilisation and its Consequences: After the Russian Movement Za chestnye vybory, "Europe-Asia Studies" vol. 69, 2017, 5, p. 771-793.

48 In April 2018 Aleksey Navalny's network was reconstructed. Finances did not allow him to keep all headquarters open any longer. The number of them fell to 29 regional branches which were singled out as the most resilient and promising, while sixteen branches agreed to remain open without pay for the workers. So thanks to this campaign Navalny gained 45 regional headquarters.

49 A. Kynev (17 April 2018). Personal interview.

50 A. V. Sokolov, Russian political crowdfunding, "Demokratizatsiya: The Journal of Post-Soviet Democratization" 2015, vol. 23, no. 2, p. 117-149. 
his campaign, published by Leonid Volkov, show the dynamics and size of the donations. Throughout the campaign 368 million roubles were collected, and the donations not only did not become smaller, but actually increased in the months following the protest ${ }^{51}$. In addition, a separate account was set up to pay the fines imposed on those who took part in the protests ${ }^{52}$. Financial support that Navalny received during the election campaign, of which an important element was the protests that he organised ${ }^{53}$, shows that the donors held Navalny's activity to be significant and desirable ${ }^{54}$. Reports on how money acquired through crowdfunding is spent not only aid the introduction of a good tradition of financial transparency to Russian politics, but also create a positive image of Navalny as the leader of the people's choice.

\section{Summary}

It emerges from this analysis that the effects of the protests organised by Aleksey Navalny in 2017 correlated positively with the growth in his political capital. The mobilisation of society in the actions described admittedly did not result in those effects that had been most anticipated - responses from the government to the corruption charges directed at the prime minister of Russia or the registration of Navalny as a presidential candidate. However, the protests had a positive influence on many factors, which determine the level of his political capital and they contributed to the realisation of several of his specific aims. Firstly, they turned into the events that challenged the ruling elite, which had focussed, above all, on finding new ideas for deprecating Navalny, thereby forcing it to react to his actions. Navalny's protests, that took place in many places in Russia, resulted in Navalny becoming a more dangerous politician from the point of view of the Kremlin's interests. The protests brought him an $8 \%$ rise in recognisability and had a positive effect on society's support for him. An important consequence of Navalny's street actions was also the change in society's perception of political protest, which has become an acceptable form of expressing one's opposition to the actions of those in power.

The protests helped Navalny test his organisational, coordination and mobilising capabilities. He was the only representative of the anti-systemic opposition who was able to mobilise the inhabitants of various parts of Russia to take to the streets in three

51 Л. Волков, Финансы кампании Навального: итоги июля, 2017, At: https://www.leonidvolkov. $\mathrm{ru} / \mathrm{p} / 223 /$, accessed September 20, 2018.

52 Л. Волков, Финальный финансовый отчет кампании Навального, 2017, https://www.leonidvolkov.ru/t/40/, accessed September 20, 2018.

53 Apart from the protests on 26 March, 12 February and 17 October analysed in this article, Navalny's team organised an election strike on 28 January.

54 Navalny's financial resources also aroused the interest of the power centre and in January 2018 the foundation's accounts, the "Fifth season", which was the financial supply network of Navalny's campaign, were frozen. „2.5 million roubles paid to the campaign were not used and the future fate of this money is difficult to predict" - wrote Leonid Volkov on his blog. Л. Волков, Финальныци финансовый отчет кампании Навального, 2017, https://www.leonidvolkov.ru/t/40/, accessed September 20, 2018". 
protests, organised in one year. This requires great organisational effort, which confirms his enthusiasm and resilience in seeking political windows of opportunity for fighting with the current regime.

Navalny's protests introduced a new factor of unpredictability and self-activation of mobilization by the opposition leader. It was a new type of protest action - generated somehow deus ex machina. This type of mobilization is a surprise for the ruling elite, because it is not a specific event (e.g. elections), the phenomenon (economic decline) that triggered street action, but only the organizer's will (when to issue a film and organize a protest). It was not Navalny who had to adapt to the existing agenda. On the contrary, the Russian elite was forced to respond to the events inspired by the oppositionist. The surprise effect is an additional problem for the ruling elite, as it may be a potential stimulus, destabilizing the political system in the future.

Admittedly, the 2017 protests did not lead to a situation in which the people started to demand alternatives to the political status quo, which could have fundamentally influenced the dynamics of mass political support for the ruling elite, although they did harm the image of the government and show that dissatisfaction with its attitude is not limited to a small circle of people from large cities.

If we perceive Aleksey Navalny as a long-distance politician, who does not focus on the immediate achievement of interim aims, then the protests as well as the whole of his action strategy during the presidential campaign are part of this far-reaching mission. This mission involves building regional support groups, testing resources, perfecting the political agenda as well as accustoming society to the activity of the real opposition vis-àvis the system. A retrospective consideration of the political history of social movements in Europe ${ }^{55}$ shows that well organised minorities with a clearly articulated agenda, that they continually update are often more successful in achieving their aims than passive and conformist majorities that hold to particular cultural and political opinions ${ }^{56}$.

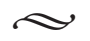

\begin{abstract}
The purpose of this article is to identify the extent to which anti-regime protests in Russia aid the anti-systemic opposition in building its political capital. The Russian authoritarian system limits participation in the political life for genuine opponents of the Kremlin, thus one way to present their objections to those in power is to organise protests and to attempt to mobilise as many citizens as possible around political slogans. Our example will be the protests organised by Aleksey Navalny and his associates in March, June and October of 2017. Protests from March and June are against
\end{abstract}

55 D. Della Porta D. (ed.) (Democracy and Social Movements, London, Palgrave Macmillan 2009; A. Giddens, The Consequences of Modernity, Cambridge, Polity Press 1990; J. Keane (ed.) Civil Society and the State, London, Verso 1989.

56 E. Chebankova, Competing ideologies of Russia's civil society, "Europe-Asia Studies" 2015, vol. 67, no 2, p. 249. 
Pobrane z czasopisma Wschód Europy http://journals.umcs.pl/we

Data: 26/04/2023 14:44:28

Protests and the political capital of anti-systemic opposition in Russia...

corruption while the October protest concerns support for Alexey Navalny as a presidential candidate. This diversification of the subject of the protests allows to specify to what extent the protests' slogans initiated by the same organizer determine public support for street action and influence the political capital of the leader of the protests. It should be remembered that due to the difficulties in precisely defining the level of the political capital of a particular politician, it seems essential to capture the trend of it, i.e. whether a given decision, policy action increased or decreased his political capital. Evaluation of the political capital of Alexei Navalny was based on such parameters as knowledge, skills, attitudes, closeness to those in power and personal resources.

Keywords: anti-systemic opposition, Political Capital, Anti-regime protests, Alexey Navalny

\section{Protesty a kapitał polityczny antysystemowej opozycji w Rosji na przykładzie antyreżimowych protestów Alekseja Nawalnego w 2017 roku}

Streszczenie: Celem artykułu jest określenie, w jakim stopniu protesty antyreżimowe w Rosji pomagają opozycji antysystemowej budować swój kapitał polityczny. Autorytarny system rosyjski ogranicza udział w życiu politycznym rzeczywistym oponentom Kremla, dlatego jednym ze sposobów przedstawienia swoich zarzutów wobec rządzących jest organizacja protestów i próba zmobilizowania wokół haseł opozycyjnych jak największej liczby obywateli. Analiza koncentruje się na protestach zorganizowanych przez Aleksieja Nawalnego i jego współpracowników w marcu, czerwcu i październiku 2017 r., przy czym dwa pierwsze to protesty przeciw korupcji, natomiast protest październikowy dotyczy poparcia dla Aleksieja Nawalnego jako kandydata na prezydenta. To zróżnicowanie tematyki protestów pozwala określić to, na ile hasła przewodnie protestów zainicjowane przez tego samego organizatora determinują społeczne poparcie dla akcji ulicznej i wpływają na kapitał polityczny lidera protestów. Należy pamiętać, że ze względu na trudności w precyzyjnym określeniu stopnia politycznego kapitału określonego polityka istotne wydaje się uchwycenie samej tendencji jego zmiany, tzn. czy dana decyzja, działanie polityka wpłynęło na zwiększenie czy zmniejszenie jego politycznego kapitału. Ewaluacja kapitału politycznego Aleksieja Nawalnego została dokonana na podstawie takich parametrów, jak wiedza, umiejętności, postawa, bliskość władzy i zasoby.

Słowa kluczowe: opozycja antysystemowa, kapitał polityczny, protesty antyreżimowe, Aleksiej Nawalny

\section{Протесты и политический капитал антисистемной оппозиции в России на примере антирежимных протестов Алексея Навального в 2017 году}

Аннотация: Цель этой статьи - определить, в какой степени антирежимные протесты в России
помогают антисистемной оппозиции в наращивании ее политического капитала. Российская
авторитарная система ограничивает участие в политической жизни реальных противников
Кремля, поэтому один из способов выразить свои возражения тем, кто находится у власти -
это организовать акции протеста и попытаться мобилизовать как можно больше граждан во-
круг политических лозунгов. В качестве примера можно привести протесты, организованные
Алексеем Навальным и его коллегами в марте, июне и октябре 2017 года. Протесты в марте
и июне направлены против коррупции, в то время как октябрьские протесты касаются под- 
держки Алексея Навального в качестве кандидата в президенты. Такая диверсификация предмета протестов позволяет указать, в какой степени лозунги протестов, инициированные одним и тем же организатором, определяют общественную поддержку уличных акций и влияют на политический капитал лидера протестов.

Ключевые слова: антисистемная оппозиция, политический капитал, антирежимные протесты, Алексей Навальный

\section{References}

Bunce V. J. \& L. Wolchik, Defeating Authoritarian Leaders in Postcommunist Countries. New York: Cambridge University Press 2011.

Casey K. L., Defining Political Capital: A Reconsideration of Bourdieu's Interconvertibility Theory, 2008, available At: https://about.illinoisstate.edu/critique/Documents/Spring\%202008/Casey.pdf. accessed 13 January 2018.

Chebankova E., Competing ideologies of Russia's civil society, "Europe-Asia Studies” 2015, vol. 67, no 2, p. 249. DOI: https://doi.org/10.1080/09668136.2014.1002695.

Civil Society and the State, J. Keane (ed.), London, Verso 1989.

Collins R., Social movements and the focus of emotional attention, [in:] J. Goodwin, J. M. Jasper \& F. Polletta (eds.) Passionate politics: Emotions and social movement, Chicago, IL: University of Chicago Press 2001.

Constitution of the Russian Federation. First Section. Chapter 1. Article 1' available at: http://www. constitution.ru/en/10003000-02.htm, Accessed 17 October 2017.

Della Porta D. \& M. Diani, Social movements, Oxford: Blackwell 1999.

Democracy and Social Movements, Della Porta D. (ed.), London, Palgrave Macmillan 2009.

Duvanova D., Russians are protesting. Part 5 Now the opposition is setting the agenda, "Washington Post"

March 2017, at: https://www.washingtonpost.com/gdpr-consent/?destination=\%2fnews\%2fmonkey-cage\%2fwp $\% 2 f 2017 \% 2 f 03 \% 2 f 31 \% 2$ frussians-are-protesting-why-part-5-now-the-opposition-is-setting-the-agenda\%2f\%3f\&utm_term=.b9e10a9636ef, accessed September 18, 2017.

Evans A.B., Jr., Protests in Russia. The Example of the Blue Buckets Society, "Demokratizatsiya: The Journal of Post-Soviet Democratization" 2018, vol. 26, no 1.

Eyerman R., How social movements move: Emotions and social movements [in:] H. Flam and D. King (eds.), Emotions and social movements. Abingdon: Routledge 2005.

French R., Political capital, "Journal of Representative Democracy" 2011, vol. 47, issue 2.available at: https://www.researchgate.net/publication/261709373_Political_Capital.

Frye T., Yakovlev A., Elections and Property Rights: A Natural Experiment From Russia, "Comparative Political Studies" 2016, vol. 49, no 4. DOl: https://doi.org/10.2139/ssrn.2695000.

Gandhi J. \& Lust-Okar E., Elections under Authoritarianism, "Annual Review of Political Science" 2009, no 12, p. 416. DOI: https://doi.org/10.1146/annurev.polisci.11.060106.095434.

Ganz M., Leading Change Leadership, Organization, and Social Movements [in:] N. Nohria \& Khurana R. (eds.) Handbook of Leadership Theory and Practice, Excerpted from Chapter 19, Harvard Business Press Boston, Massachusetts 2010, available at: http://marshallganz.usmblogs.com/ 
Pobrane z czasopisma Wschód Europy http://journals.umcs.pl/we

Data: 26/04/2023 14:44:28

Protests and the political capital of anti-systemic opposition in Russia...

files/2012/08/Chapter-19-Leading-Change-Leadership-Organization-and-Social-Movements.pdf, accessed 7 March 2019.

Gerber T. P., Russians are protesting. Part 2: Any government response will bring out more protesters.

"Washington Post" March 2017, at:https://www.washingtonpost.com/news/monkey-cage/ wp/2017/03/31/russians-are-protesting-why-part-2-any-government-response-will-bring-outmore-protesters/?utm_term=.2ac3ec138c76, accessed September 18, 2017

Giddens A., The Consequences of Modernity, Cambridge, Polity Press 1990.

Golosov G. V., Die ideologischen Positionen der Regierung und der Opposition in Russland, "Russland-Analysen" 2018, no. 355, p. 2. At: http://www.laender-analysen.de/russland/pdf/RusslandAnalysen355.pdf, accessed September 28, 2018.

Goodwin J., \& Pfaff S., Emotion work in high-risk social movements, [in:] J. Goodwin, J. M. Jasper \& F. Polletta (eds.) Passionate politics: Emotions and social movement, Chicago, IL: University of Chicago Press 2001.

Grigoriev I. S. \& A. A. Dekalchuk, Collective learning and regime dynamics under uncertainty: labour reform and the way to autocracy in Russia, "Demokratizatsiya: The Journal of Post-Soviet Democratization" 2017, vol. 24, no 3. DOl: https://doi.org/10.1080/13510347.2016.1223629.

Gudkov L., The nature of Putinism, "The Public Opinion Herald" 2003, vol. 3, no 101, p. 11.

He is Dimon to you. Anti-Corruption Foundation. 2017. At: https://www.youtube.com/watch?v=qrwlk7_ GF9g, accessed April 13, 2018.

https://www.bbc.com/news/world-europe-47488267, accessed 5 April 2019.

Jasper J. M.., Emotion and Motivation, [in:] Robert E. Goodin and Charles Tilly (eds), Oxford Handbook of Contextual Political Studies. Oxford: Oxford University Press 2006.

Kara-Murza V. V., The Kremlin Emboldened: Putin Is Not Russia, "'Journal of Democracy" 2017, vol. 28, no 4, p. 114. Dol: https://doi.org/10.1353/jod.2017.0071.

Kolesnikov A., New Protests Question Russia's Social Contract. "Carnegie Europe" 2017, at: http:// carnegieeurope.eu/strategiceurope/71283, accessed February 20, 2018.

Lasnier V., Demobilisation and its Consequences: After the Russian Movement Za chestnye vybory, "Europe-Asia Studies" 2017, vol. 69, p. 5. DOl: https://doi.org/10.1080/09668136.2017.1332166.

Lee Ch. K. and Yonghong Zhang, The Power of Instability:Unraveling the Microfoundations of Bargained Authoritarianismin China, "American Journal of Sociology" 2013, vol. 118, no 6. DOl: https://doi. org/10.1086/670802.

Lyall J. M. K., Pocket Protests Rhetorical Coercion and the Micropolitics of Collective Action in Semiauthoritarian Regimes', "World Politics" 2006, vol. 58, no 3, p.381.

Nechai V., Goncharov D., Russian Anti-corruption Protests: How Russian Twitter Sees It?, "Digital Transformation and Global Society" 2017, vol. 21, no 33. DOl: https://doi.org/10.1007/978-3-319-69784$0 \_23$.

Olson M., The Logic of Collective Action, Cambridge: Harvard University Press 1971.

Omelicheva M., New wave of protests in Russia (the old and the new, "PONARS Eurasia 2017, at: http:// www.ponarseurasia.org/article/new-wave-protests-russia-old-and-new, accessed July 19, 2017.

Østbø J., Between Opportunist Revolutionaries and Mediating Spoilers: Failed Politicization of the Russian Truck Drivers' Protest, 2015-2016, "Demokratizatsiya: The Journal of Post-Soviet Democratization" 2017, vol. 25, no 3. 
Ostrom E., A Behavioral Approach to the Rational Choice Theory of Collective Action, "American Political Science Review" 92, 1998. DOl: https://doi.org/10.2307/2585925.

Przeworski A., Democracy and the Market: Political and Economic Reforms in Eastern Europe and Latin America (Cambridge, Cambridge University Press) 1991, p. 58.

Putin signs law imposing penalties on protest organizers for involving children in Russian rallies, Washington Post, 28 December 2018, available at: https://www.washingtontimes.com/news/2018/ dec/28/putin-signs-law-imposing-penalties-on-protest-orga/, accessed 15 April 2019.

Rethinking social movements: Structure, meaning, and emotion, Goodwin J. \& Jasper J. M. (eds.), Lanham, MD: Rowman and Littlefield 2004.

Robertson G. B., The Politics of Protest in Hybrid Regimes: Managing Dissent in Post-Communist Russia, NewYork:Cambridge University Press 2011.

Russia laws ban 'disrespect' of government and 'fake news, BBC, 7 March 2019, available at:

Schugurensky D., Citizenship Learning and Democratic Engagement: Political Capital Revisited, Paper presented at the 41st Annual Adult Education Research Conference. Vancouver: AERC, June 2-4, 2000. Published in Conference Proceedings

Sokolov A. V., Russian political crowdfunding, "Demokratizatsiya: The Journal of Post-Soviet Democratization" 2015, vol. 23, no 2.

Sørensen E. \& Torfing J., Network Politics, Political Capital and Democracy, "International Journal of Public Administration" 2003, vol. 23, no 6. DOl: https://doi.org/10.1081/PAD-120019238.

Stepan A., On the Tasks of a Democratic Opposition, "Journal of Democracy" 1990, vol. 1, no 2. DOl: https://doi.org/10.1353/jod.1990.0021.

Tarrow S., Power in Movement: Collective Action, Social Movements and Politics. N.Y., Cambridge: Cambridge University Press 1994.

\section{Interviews}

\section{Russian-language publications:}

Borusyak L. F., Molodyye uchastniki protestov: pochemu oni vykhodyat na ulitsy? XIX Aprel'skaya mezhdunarodnaya nauchnaya konferentsiya po problemam razvitiya ekonomiki i obshchestva, 10-13 aprelya 2018 https://conf.hse.ru/2018/program/, p. 3.

Kleman K., Pod"yem grazhdanskikh protestnykh dvizheniy v zakrytoy politicheskoy sisteme: potentsial'nyy vyzov gospodstvuyushchim vlastnym otnosheniyam?, 2006, http://www.isras.ru/files/File/publ/Vyzov_vlast_otnosch_Kleman.pdf,

Kuznetsova E., V. Dergachev., Iyun'skiye protesty ne dobavili Naval'nomu populyarnosti, https://www.levada.ru/2017/07/17/iyunskie-protesty-ne-dobavili-navalnomu-populyarnosti/

Tatarkova D.Yu., Nesistemnaya oppozitsiya kak spetsifika prezentatsii v pechatnykh SMI, „Polis”. 2013. No. 4. Skol'ko lyudey vyshli na ulitsy 26 marta i skol'ko zaderzhali? Karta protesta, "Meduza", 27 March 2017, available at: https://meduza.io/feature/2017/03/27/skolko-lyudey-vyshli-na-ulitsy-26-marta-iskolko-zaderzhali-karta-protesta, accessed 10 June 2017

Sotsiolog o tom, kak Naval'nyy vliyayet na protesty v Rossii, DW , November 2017, available at:http:// www.dw.com/ru/sociolog-o-tom-kak-naval'nyj-vlijaet-na-protesty-v-rossii/a-41281904, accessed 28 September 2018. 
Pobrane z czasopisma Wschód Europy http://journals.umes.pl/we

Data: 26/04/2023 14:44:28

Protests and the political capital of anti-systemic opposition in Russia...

Sonnaya K., A. Vikulova, «Delo 26 marta» - kto eti lyudi i za chto ikh sudyat. Gid OVD-Info, 7 December 2017, available at: https://ovdinfo.org/articles/2017/12/07/delo-26-marta-kto-eti-lyudi-i-za-chtoih-sudyat-gid-ovd-info, accessed 11March 2018.

Volkov D., Predposylki dlya osennikh protestov, https://www.levada.ru/2018/08/16/predposylki-dlyaosennih-protestov/

Volkov V., Finansy kampanii Naval'nogo: itogi iyulya, 2017, At: https://www.leonidvolkov.ru/p/223/, accessed September 20, 2018.

Volkov V.., Final'nyy finansovyy otchet kampanii Naval'nogo, 2017, https://www.leonidvolkov.ru/t/40/, accessed September 20, 2018.

7 oktyabrya 2017 goda. Zaderzhaniya po vsey Rossii. Spisok 8 October 2017, available at: https://ovdinfo.org/news/2017/10/08/7-oktyabrya-2017-goda-zaderzhaniya-po-vsey-rossii-spisok, accessed 11 March 2018.

12 iyunya na ulitsy vyshlo bol'she lyudey, chem 26 marta Karta protestov «Meduzy» i «OVD-Info». Samyye polnyye dannyye, "Meduza” 13 June 2017, available at: https://meduza.io/feature/2017/06/13/ skolko-lyudey-protestovali-12-iyunya-i-skolko-zaderzhali, accessed 15 July 2017.

7 oktyabrya: protestnaya karta. Gde i skol'ko lyudey vyshlo, skol'ko zaderzhali Sovmestnyy proyekt «Meduzy» i «OVD-Info», "Meduza" 8 October 2017, available at https://meduza.io/feature/2017/10/10/7-oktyabrya-protestnaya-karta-gde---skolko-lyudey-vyshlo-skolko-zaderzhali, accessed 15 January 2018.

Priblizitel'noye raspisaniye otkrytiy shtabov, VK,16 February 2017, available at: https://vk.com/topic-55284725_34990538, accessed 16 May 2018.

Levada.ru July 2017, at: https://www.levada.ru/2017/07/17/iyunskie-protesty-ne-dobavili-navalnomupopulyarnosti/, accessed September 20, 2018.

Gelman V. (5 February 2018). Personal interview.

Titkov A. (12 April 2018). Personal interview.

Kynev A. (17 April 2018). Personal interview Navalny's co-workers in Saint Petersburg (9 February 2018). Personal interview.

Navalny's co-workers in Moscow, (18 April 2018). Personal interview. 